\title{
Services of General Economic Interest In-between EU and Italian Law
}

\author{
Marchian Giovanna \\ Department of Sociology and Economic Law, University of Bologna, Italy
}

Copyright $(\mathcal{C} 2015$ by authors, all rights reserved. Authors agree that this article remains permanently open access under the terms of the Creative Commons Attribution License 4.0 International License

\begin{abstract}
Introduction and demarcation of the inquiry on SGEIs; 2-. The notion of services of general economic interest and its relation to public economic service in the Italian system; 3-. The progressive definition of minimum competition rules for SGEIs: comparative profiles between national regulation and Europe inspired principles; 4-. SGEIs: competitiveness, proportionality and balance within the framework of EU principles. 5-. National regulations on local public services of economic interest: the difficult implementation of EU principles in Italy; 6-. Management models: from the bureaucratic model to the functional model
\end{abstract}

Keywords General Economic Interest, Public Economic Service

\section{Introduction and Demarcation of the Inquiry on SGEIs}

It is recent news that a European Commission's study, elaborated by the Italian Confartigianato (the National Craft Trades Confederation), has highlighted the problem of the quality of public services in Italy, moreover noting the increase that fees for the latter have experienced in the last few years. The investigation, indeed, using as its reference the data of 2013, pointed out that fees for services increased $49,2 \%$ compared to previous years and in any case, as reported by the Italian press, three times more than the European average.

Customers are unfortunately already well aware of the datum, and the motives may be ascribed to a series of interlinking economic and non-economic factors. However, Italian resistance to the application of the principle of competition between the services is to be considered the determining factor in the increase, connected as it is to management models far removed from competition, and, moreover, protected by political choices. The most striking example is the Italian water service, which was the object of a referendum to repeal Article 23 (b) of Law Decree no. 112 of 25 June 2008 which had extended to the former a pro competition regulation for local services of general economic interest. The referendum not only repealed the abovementioned provisions, but also those under Article 154, (a) of the Legislative Decree no. 152 of 3 April 2006, where it provided that the fee for the water service should also be calculated considering «the adequacy of the financial remuneration of the capital invested».

The Court excluded that the requirements of the referendum were in contrast with EU law, since the obligation of managing general public services according to the rules of the externalisation of the supply of the services went beyond the minimum requirements of competition required under EU law. However, such a profile, which cannot be dealt with here, does not appear wholly convincing. The admissibility of these referendum requirements derives from the fact that the introduction of more stringent rules of competition on the part of the Italian legislators was not directly derived from EU law, although not necessarily in contrast with its provisions. What brought about the admissibility of the referendum is the «onwards thrust» of the Italian legislators compared to EU principles, forcing the Court, however, also in consequence of the result of the referendum, to restate how the inspiring principles of the field are those to be found within the EU system.

Indeed, the Court, as will be later shown, reached the conclusion that, given the outcome of the referendum, not to mention the repealing of national regulations, the legal regimen of local public services of economic interest is directly defined by the EU system and not by the national laws predating the referendum. It is observable that we are facing a critical point in the relationship between EU and national law sources: the bone of contention is not the contrast between national and EU regulations, but the «space» national laws have acquired compared to EU sanctioned principles. It was moreover predictable that the instrument represented by the abrogative referendum, with its limitations, which are well known to Italian constitutionalists, was not a wise choice to criticise the onward rush of the legislators; this is confirmed by the subsequent regulations of the sector, which fundamentally 
reprise the configuration preceding the repealing referendum. In any case it is necessary to observe that following the legislative vacuum thus created, Law Decree no. 138 of 13.08.2011 was issued, confirming the general principle of the competitive management of SGEI, with the exclusion of the water service. The provision was declared unconstitutional by the Supreme Court on the basis of the remark that the matter had the effect of reintroducing the regulations repealed by the referendum, thus violating article 75 of the Italian Constitution. Sentence 199/2012 reads: the few changes introduced by Article 4 enhance the drastic reduction of the possibilities of directly assigning local public services that the referendum had aimed at excluding [...] while the repealing intentions expressed by the referendum involved practically all local public services having economic relevance [...] it not being possible to consider the exclusion from the application of such discipline to water services as satisfying the will expressed by the consultation of the population". The result of the referendum imposed the necessity of avoiding that its result be annulled, frustrating its usefulness, in the absence of significant changes to the regulatory framework, despite the EU framework remaining stable.

The above mentioned legal issue gives the chance to trace, although only within the boundaries of the present paper, the main focal points of the EU regulation on the matter, for the purpose of verifying its innovative elements compared to the repealed Italian regulation.

In this perspective, the so called «SGEI package» adopted in Brussels on 20.12.2011 must be examined in relation to certain national provisions included in the so called "Saving Italy" legislative decree, successively converted in Law no. 214 of 22 December 2011, n. 214, as well as the fragmentary provisions under Article 34 of law decree 179/2012, converted in Law No. 221/201.

However, it is to be remarked how such provisions do not add any innovative elements to the matter since they are linked by the same regulatory system of SGEIs which preceded the referendum and are fundamentally steeped in repetitions of programming formulae leading to the absence of concretely applicable measures, and as such, lacking innovative capabilities in the matter. The purpose is demonstrating how, despite the Constitutional Court's intervention, services of economic interest resulted and should result subject by EU principles, by which the Italian legislature was inspired even before the referendum, and to which, as point of law, the Constitutional Court referred. Hence the reflection that, in virtue of the reference to the EU system stated in the Court's judgement as a pivotal principle of the matter, it is necessary to actuate that pro-competitive set up that was also the inspiration of the legislature before the referendum and whose effects would, moreover, influence the fees charged to users.

An element of prompting to legislators may however be inferred from the Constitutional Court's sentences, in order that the former reach a different discipline between services of economic interest and general public services. Blending the Court's judgements with EU principles, the regulatory landscape is characterized by the fact that, either services are carried out under a private law system, removing them from the class of public services of economic interest, such as water services, or the general rule calls for the services being supplied in free competition. Such a statement, which may strike as being too simplistic, is actually laid down by the Italian Constitutional Court itself, which pointed out that the overall design of referenda, linked by a «same "political" purpose, is that of carrying water from the normative framework of services of general economic relevance to that of the social services, dominated, according to the introductory report of the Promoting Committee, by a public law managerial model pivoting on special companies",.

On closer inspection the above mentioned remarks are evidence of the thesis that does not see in Judgement No. 199/2012 a revision of the EU centred architecture on general economic services, which is in any case referenced by the Constitutional Court, but an actual division between public economic services and public services: if the water service is considered a service to be managed outside and beyond market rules, it should fall under the category of so called public services, full stop, and as such adopt a management model so to speak "within" the public administration, traditionally identifiable, within the Italian system, with the «special company» model.

It is noteworthy that also on the matter of the tariff system for the coverage of costs for the integrated water system the Italian Administrative Courts ${ }^{2}$ have recently referred to pre-referendum regulations; the Administrative Court stated that, also in the light of the Judgment of the Constitutional Court n. 325/2000, classifying integrated water services within services of economic interest, the service keeps being characterised, as regards tariffs, by the necessity of full cost recovery. The principle of cost recovery is explicitly referenced, not just at a national level but also at EU level, under Article 9 of Directive $2000 / 60 / \mathrm{CE}^{3}$, transferring the onus of recovering of costs for water services to Member States.

The Constitutional court, admitting the referendum repealing Article 154, claimed that "profit based logics" should be kept without the management of water resources; however, it must be allowed that in subsequent judgments, for instance Judgement no. 67/2033, the courts confirmed the necessity for water services of full cost recovery. Thus, the Italian Regulatory Authority for Electricity Gas and Water ${ }^{4}$, in its Decision no. 585/2012, initially excluded any remuneration for invested capital, which would contrast with the outcome of the referendum, acknowledging, however,

\footnotetext{
${ }^{1}$ See G. Caparezza Figlia, Concorrenza e contratto nei mercati dei servizi pubblici locali, in Riv. Dir. impr., n. 1/2012, p. 40.

2 TAR Lombardia, 26 March 2014, n. 779.

3 Article 9 European Directive CE 60/2000.

4 See the Italian Authority's Decision no. 585/2012, Approvazione del metodo tariffario transitorio (MTT) per la determinazione delle tariffe negli anni 2012 e 2013, and subsequent Decision of 27 December 2013 no. 643/2013, Approvazione del metodo tariffario idrico e delle disposizioni di completamento.
} 
that, on the basis of the EU principle of the necessity for full cost recovery, the tariffs should cover both the financial cost and the tax load of the management of the service. All this has led to a substantial re-proposal of the tariff method provided for under the regulations preceding the referendum ${ }^{5}$.

\section{The "Notion" of SGEI and its Relationship with the Notion of Economic Public Service in the Italian System}

The European Union, albeit with a prudent attitude towards Member States, has lately tried to homogenise the internal laws of single countries relatively to the regulation of public services, with particular reference to services of general economic interest. This originates from the fact that the EC gradually abandoned its attitude of substantial neutrality towards the choices made by Member States on the institution and the organisation of their public services, in order to realise, also in this sector, an open and free competition market economy, within the framework of the European market and the protection of economic freedoms.

It must be borne in mind that from the very start the Union acknowledged an ample discretion to Member States in pursuing their interests through public services, with the only provision that in the case of these services, there emerged a higher index of political and general interest, compared to other economic endeavours. On this point, however, in those years the Court of Justice never criticised the reasonableness or the choices on the organisation of public services, even when these disregarded the principles on competitions stated in the Treaties.

Nonetheless, the greater integration imposed by the European single market made the Community's neutral stance recede, starting from the Single European Act of 1986, and, more blatantly, with the signing of the Treaty of Maastricht of 1992 and the subsequent Treaty of Amsterdam of 1997; the latter stressed the importance of services within the Union's common values, providing that $«[\ldots$ the Community and the Member States, each within their respective powers and within the scope of application of the Treaties, shall take care that such services operate on the basis of principles and conditions, [...], which enable them to fulfil their missions». There emerges then a greater awareness of the role of public services not just within the Member State systems, but also in the integration process of the Common markets. Indeed, the Lisbon Treaty itself proposes the matter again, with the exception of the Member States' jurisdiction in supplying, implementing and

5 See in particular Ministerial Decree no. 243 of 1 August 1996, n. 243, Metodo normalizzato per la definizione delle componenti di costo e la determinazione della tariffa di riferimento del servizio idrico integrato, in G.U., 16 ottobre 1996. financing such services. The Court of Justice case-law is also part of this integration process, by accentuating, in its decisions, the growing rise in importance of the Union's economic objectives, forcefully stating the primary role of the protection of economic freedoms within the framework of the Community system ${ }^{6}$.

Consequently, in the late 90 s, specific rules on the role of Member States on services of general economic interest were inserted in primary EU provisions, leading to the exclusion of an ontological approach to the matter, as can be inferred from Directive 123/2006/EC on services, which provides that it «does not affect the freedom of Member States to define, [...] what they consider to be services of general economic interest» Article 1(3)(2).

However, the homogenisation process between national laws on the matter presumes a uniform notion of service of general economic interest, to wit that the concept of SGEI be identified in all States on the basis of the same principles, a fact that is as yet not traceable in the single legislations, which thus leads to non-univocal interpretations, both on the part of the Union, and of the single Member States.

The birth of the locution «public services of general interest», does not only represent a nominalist expression, but rather an actual new legal category, created by EU law to give an answer to the coexistence of more meanings ascribable to the notion of public service, which was an element characterising the principles developed by Member State law systems. The difficulty in identifying the concept under scrutiny also derives from the fact that the Treaties do not choose to use the locution «public service» ${ }^{7}$, electing, instead, the expression «services of general economic interest ${ }^{8}$, subjecting the whole discipline to the provisions under Article 106 TFEU. It is in this very article, for that matter, that there emerges the different relevance of «services of general economic interest» and «services of general interest»: only the former are subject on the regulations on competition, while this cannot happen in the case of the latter.

Nor can possible simplifications be of help to the interpreter: this because an identification of SGEIs is lacking, since no «class» of services that may be used as a factual touchstone is to be found. The fact is that the choice of not limiting SGEIs is the outcome of a compromising approach carried out by the Union, to link the principle of subsidiarity with the principle of the cost effectiveness of the service; if on the one hand, the needs of the customer citizens, and on the other, the peculiar bond between such activities and the public powers of the single Member States must be considered.

Hence the remark that the notion of service of general

\footnotetext{
6 See Judgment of the Court of 19 March 1991. French Republic V Commission of the European Communities. Competition in the markets in telecommunications terminals equipment. Case C-202/88.

7 Only appearing in Article 93 TFEU on transport.

8 As can be seen in Articles 14 and 16 of the TFUE.
} 
economic interest ${ }^{9}$ - even when there is a desire to highlight its economic character - is fundamentally just descriptive, due to the potential conflict between the matter and the market ${ }^{10}$ : on one hand, the connection of the «economic» profile of the services is aimed at avoiding that these free themselves with excessive nonchalance from the principles of EU law, on the other, however, the specificity of the general interest they are endowed with in the expectations of citizens bears both on EU and single Member States' regulations.

Under the relevant aspect it is to be believed that even if «services of general economic interest» and services of general interest are notions created in different contexts and still today the object of discussion on the matter of their distinction, it seems that it can safely be stated that they have assumed the relationship between a general category and a more specific one, and it is in this sense that in the present paper the intention is superimposing, if not identifying, under Article 6 TFEU, SGEIs with services of economic interest $^{11}$. This mindset is modelled on the specifications under point 44 of the Green paper on services of general interest, 21 May, 2012 which states: «As regards the distinction between services of an economic nature and services of a non-economic nature, any activity consisting in offering goods and services on a given market is an economic activity. Thus, economic and non-economic services can co-exist within the same sector and sometimes even be provided by the same organisation. Furthermore, while there may be no market for the provision of particular services to the public, there may nevertheless be an upstream market where undertakings contract with the public authorities to provide these services. The internal market, competition and state aid rules apply to such upstream markets».

The motivation of this distinction, in truth, did not and does not represent a real discriminator between the two categories, to the point that the European Parliament subsequently approved a resolution ${ }^{12}$ in which it «Notes with concern in this connection recent attempts to apply to certain SSGIs rules and principles appropriate to other services including services of general economic interest, without taking into account the factors and principles which

\footnotetext{
9 The problem of trying to unite the subject also emerges in the European Commission's communication of 20.12.2011 COM (2011), 900 final $A$ Quality Framework for Services of General Interest in Europe, which was an attenpt to create a general framework on services a a "broad" category within which various types of services may be included, amongst which those of general economic interest.

10 The fact is that the Court outlines the concept of economic service, using negative and not positive criteria. It can thus be claimed that the category of services of general economic interest includes those categories of public services having economic relevance for which States (and their territorial divisions) assume full responsibility..

11 Services of general interest in Europe. Communication from the Commission. COM (2000) 580 final, 20 September 2000, Paragraph 28. See also Communication from the Commission. Implementing the Community Lisbon programme: Social services of general interest in the European Union 26.4.2006, COM(2006) 177 final, Paragraph 1(1).

12 Observe how the acronym SSGI stands for Social Services of General Interest. European Parliament resolution of 14 March 2007 on social services of general interest in the European Union (2006/2134(INI))
}

distinguish SSGIs from other services»». It is noteworthy that, in this context, the European Commission, identifying the principles underpinning Article TFEU, not only referred to the principle of neutrality in the case of public or private property of the undertakings, but also the principle of proportionality, which implies that the means to achieve missions of general interest should not give rise to unnecessary distortions in the market. In this picture, moreover, there emerges the Union jurisdiction rather than the single Member States': under Article 14 TFEU, the European Union establishes the principles and sets the conditions enabling the undertakings to accomplish the mission entrusted to them, while Member States are to furnish, organise and finance said services 13 .

However, mention must be made of the fact that the notion of service of general economic interest does not exhaust its meaning within the framework of the so called «rules of competition» under Article 106 TFEU; indeed (under Article 14 TFEU) the provision for a right of protection of citizen-users from the State, bound to furnish the service of general economic interest, can find in article 106 a mere instrument and not a concept. As has been remarked: «[...] the guarantee of the service according to requirements of quality, cost effectiveness and continuity [...] is not completed [...]by excluding competition: in fact, Article 106 lays down that the closure of the market should be only considered an exception, the public sector being allowed to proceed in that sense only provided it respects the principle of necessity and proportionality» 14 .

The possible overlapping of «services of general economic interest» and "services of economic relevance», is moreover referred to «also» by the Italian Constitutional Court in its judgement no. 325/2010, where the court remarked that both «fulfil [...] [the] function of identifying services whose management should generally be carried out, in order to protect competition, by committing it to third parties according to public tenders» 15 . On the matter it has been observed that in this judgement there is reference to a unitary concept of the market inspired by the principle of competition. However, the unity of the concept the Court references cannot be exclusively identified with the adoption of the prescribed competitive procedures to tender public contracts under a system protecting the free market economy, the latter representing a specific aspect of the wider matter of the opening to the market of public economic services. The pivotal point of the reasoning identifiable in the sentence is

13 See, in this sense, the Court Of Justice, judgement of 30 April 1974, C-155/73, Sacchi, according to which it is observed that the Union does not enter into judgement of Member States' political choices relatively to the organisation of SGEIs, so that the attribution of special or exclusive rights does not constitute, per se, a measure contrary to the Treaty. Judgement of the Court of Justice, 19 January 1994, C-364/92, SAT Fluggesellschaft; Judgement of 18 March 1997, C-343/95, Diego Cali \& sons.

14 M. Maresca, Crisi della Comunità di diritto nell'Unione europea, in Diritto e politiche dell'Unione europea, 2007, fasc. 3, pp. 51-70.

15 Judgement of the Italian Constitutional Court no. 325/2010, point. 6.1. We agree with the Court, on the relevant matter, in equating Services of General Public Interest (under Article 106 TFEU) with public services of economic relevance. 
not in its reference to tender procedures, but in the reference to the principle of competition as the forthcoming principle of economic activities ascribable to the notion of public economic service.

A new cause for reflection is moreover introduced: under Article 57 TFEU, «services» are to be understood to mean the provision of services, which is of activities of an industrial or commercial character, of craftsmen, and of the professions - but not necessarily for remuneration. In this interpretation, services are also to be considered «objects of business management» and, as such, encompass «every entity engaged in an economic activity, regardless of the legal status of the entity and the way in which it is financed ». Conversely, it must not be forgotten that «economic activity» in to be understood as meaning the offer of goods and services within a given market. Therefore, all subjects operating within the market are to be considered undertakings under Articles 102 and 106 TFEU.

The European Commission on services of general interest remarked that «[i]n general, internal market and competition rules, do not apply to non-economic activities and therefore have no impact on services of general interest to the extent to which these services constitute non-economic activities» ${ }^{16}$.

This mindset is restated in the «Green Paper on services of general interest» ${ }^{17}$, where the Commission stated that the rules of competition only apply to economic activities, after having pointed out that the distinction between economic and non-economic activities is dynamic and evolving, thus it would not be feasible to define a priori list of the services of general interest of a non-economic nature.

It should moreover be pointed out that also Italian courts ${ }^{18}$ have taken the same stance regarding the impossibility of identifying a static criterion to distinguish between economic and non-economic activities, referring to the incessant EU case-law, and considering the fact that the absence of a profit making goal is not a determining circumstance to define a service as "non-economic public service".

Hence reference is made to all economic operators, even those who recently appeared on the market or that combine economic activities with social aims, whose development is different due to the differing national regulations ${ }^{19}$. Notwithstanding the permanence of several distinctions, today there prevails, as common "heritage", the mindset adopted by EU courts, who have more than once stressed that

${ }^{16}$ Communication from the Commission - Services of general interest in Europe, 20 September 2000, * COM(2000), 580 final, paragraph 28.

17 Green Paper on services of general interest, COM (2003) 270 final, 21 May 2003

18 Cons. Stato, sez. V, 23.10.2012, n. 5409.

19 According to EU case-law, profit making nature does not have decisive value in evaluating if the activity is an economic one or not. See Judgement of the Court of Justice of 21 September 1999, C-67/96, Albany International $B V$, point 85 . See also Judgment of the Court of Justice 22 May $2003, \mathrm{C}-18 / 2001$

In the Italian system there have been contrary positions, see opinion of the Corte dei Conti no. 195/2009, where it is remarked that the production of goods and services provided free or at a political price cannot be considered an economic activity, «since this objectively excludes the possibility of covering costs with the proceeds, which would lead to the exclusion of entrepreneurial activity». the notion of economic activity incorporates any activity offering goods and services in the market, whatever the public or private nature of the managing subject, or its financing, and whatever the aims or object pursued, thus the non-profit qualification of the undertaking proves to be indifferent to the ends of the present approach. This prospective was proposed again already in the Protocol attached to the Lisbon Treaty, whence it is inferred that, on the contents of the SGEIs, the latter shall guarantee, in their performance, a «high level of quality, safety and affordability, equal treatment and the promotion of universal access and of user rights»; as regards their aims, relevance is given to the «mission» conferred on SGEIs, which represents, on closer inspection, the legal and factual premise allowing the provider undertakings to enjoy special rights, that is to receive public grants and subsidies, without prejudice to the principle of the prohibition of State Aids.

There derives, to exemplify, that according to the Union, undertakings providing SGEIs must be subject to the principles of EU law, and, consequently, the principle of competition, provided that its implementation does not jeopardise the general interest the services are designed to fulfil.

\section{The Progressive Definition of Minimum Competition Rules for SGEIS: Comparative Profiles between National Regulation and Europe Inspired Principles}

It is impossible to refer here to all the ample debate at European level on the matter, however it is expedient to highlight that for European law, the main objective was, and is, harmonising Single Member States regulations on the matter, opening the sector to competition, and limiting to just the hypothesis provided under Article 106 TFEU the adoption of measures legitimising public service activities under private law regulations; this because Common Market regulations imply the prohibition of limiting economic activities within the Union market. From the above mentioned EU principles, there derived Directive 2006/123/EC on internal market services, which provided, under Article 1(3)(2), that «[t] his Directive does not affect the freedom of Member States to define, in conformity with Community law, what they consider to be services of general economic interest, how those services should be organised and financed, in compliance with the State aid rules, and what specific obligations they should be subject to». The Directive did not aim at regulating in detail, but rather at coordinating, albeit leaving ample freedom to Member States, the general framework on the premise of ensuring freedom of establishment and free movement, and thus to streamline, via «selective regulation», those elements which were identifiable as impediments to the recognised pro competition level of the former, also on the basis of the 
reference to the social function, i.e. the subsidiarity principle which has always characterised the service sector on the whole. The Services Directive, according to the typical model of first generation Directives, had a negative connotation: providing for the elimination of the existing barriers to the free provision of services within the national systems. The adoption of a common framework of rules on general economic services was supposed to open the way to a positive integration by means of the provision for minimum standards Member States were to comply with.

Although the Services Directive was a limited impact one, it certainly had significant relevance in outlining what is defined as acquis communitaire, which moreover was and still is founded on principles such as freedom of establishment and of subsidiarity. However, in this contact, it must be stressed that in Italy public services have always been permeated by monopolistic criteria, or at any rate tending towards monopoly, this because the actions of public powers in the sector surveyed was characterised by the adoption of political choices completely lacking all economic reflection.

It must be borne in mind that in the Italian system, much more markedly than in the EU one, the nucleus of planning public services in general, and also those of economic relevance, was identified in the premise that such services should respond to an exponential interest of the relevant community, so as to absolutely exclude any external management thereof; consequently, choices relative to the preparation or the organisation of the former always followed the parameter of political assessment, without any consideration of the economic repercussions of the activities undertaken in a given market, economic repercussions which moreover redounded, and redound, upon citizens, also in the matter of tariffs; all this has led to the creation of service delivery systems that, despite operating under a monopolistic regime $^{20}$, have loaded a non-insignificant economic burden on public finances.

It is no coincidence that the typical model for the management of services has always been companies taken over by the municipal authorities (undertakings in which all or a majority of the capital is publicly owned) as the paradigmatic legal format for the provision of the former services, considering that such a model ensured a social function in the pursuit of general utility goals. The collocation of a resource outside profit making logic took on the role of prerequisite to the allocation of providing the latter to a public sector subject, entrenched in the administrative apparatus.

The fact is that in the field examined, up to the present day, there remain two directives characterising the matter, that is the principle of competition, and the social profile of public services (better: the principle of subsidiarity). It must be

20 This emerges from the Green paper on services of general interest of 21 May 2003 (COM-2003-2007), 270 def., pt. 20, where it is stressed that it refers to a service offered to the general public, to whose provision a specific role in the public interest has been assigned without any reference to the subjects providing said services. taken into account that within the Italian system the fact that the latter principle has always been prevalent and has overborne the former, preventing any entrepreneurial discipline, so as to lead to protectionist regulations on the part of public administration. This however has not excluded the legislature from going beyond these - starting from the adoption of the Financial Law of 2004, and DLgs no. 59/2010 and of the subsequent legislative acts which will be examined later - by imposing a distinction between public services tout court and services having economic relevance; distinction that led, in the case of the latter, to the introduction of the principle of competition according to the market laws, actually strengthening the EU settings.

To contextualise the relationship between EU principles and the principles of the Italian system, the best thing is to start from an unavoidable datum: form the judicial viewpoint the pro competition regulations provided for at EU level would find no obstacles in the Italian system, being fundamentally validated under Article 41 of the Italian Constitution, besides an analogous concept also found in the updated text of Article 117 of the latter, which refers to «the same principle to be found under Article $119 T_{F E U^{21}}{ }^{\prime}$, that is the commitment on the part of Member States and of the Union to adopt economic policies in conformity to an open and free competition economy.

Having said that, Article 117 of the Constitution precludes a legal typifying on the part of the Central State authority allowing it to impose management models to the detriment of local autonomies, as the Courts have moreover upheld, but that does not per se exclude the pro competition regulation of economic public services already to be found, in embryo, in the Financial Law for 2004 and taken up again in subsequent laws on the matter. The Constitutional Court, in its ruling No. $272 / 2004$, called attention to the fact that protection of competition under Article 117 (2)(c) is a «transversal» matter, intersecting the regional jurisdiction recognised by the Constitutional Charter, but did not preclude a regulation based on the principle of the competitiveness of services. The Court criticised the fact that neither regulation under Article 23 (a) of Legislative Decree 112/2008, nor that under Article 4 of Legislative Decree 138/2011, provide for the recognition of regional jurisdiction.

Hence on the level of principles, and despite the features of the Italian system on the relationship between the State and Regions, it must be recognised that only when public authority considers a service must be removed from the market to achieve its ends, it shall be possible to manage said service outsides the rules of free competition, in consideration of the prevalent character of the function linked to the interests of the community, according to the prospectus already furnished under the Directive of services. Although there is no real coincidence between the principle

${ }^{21}$ In F. Trimarchi Banfi, Procedure concorrenziali e regole di concorrenza nel diritto dell'Unione e nella Costituzione (all'indomani della dichiarazione di illegittimità delle norme sulla gestione dei servizi pubblici economici); in Riv. It. Dir. Pub. Com. no. 5/2012. 
of competition sanctioned at an EU level, and competition as provided for under Article 117 of the Italian Constitution - a most critical point identified by Italian scholars in the Constitutional Court's judgement - and except for the specific repartition between the State and the Regions stated in the same article, it must be noticed that also in the Italian, like in the EU system, services of economic public interest are subject to the principles of market economy, with the exception of a differing will on the part of the political authorities, on the basis of the services' mission.

To simplify at the utmost, it is manifest that the liberalisation of economic activities, as a tool to promote competition, is the primary condition for the introduction of pro competition regulation in the sector on the part of State and regional legislature in the framework of their relative jurisdictions. However, state and regional regulations on the matter are subject to Article 106(2) TFEU, which must be understood in conjunction with Article 106(1); therein derogations are admitted when this is necessary to allow the undertakings entrusted with operating services of general economic interest to perform the tasks assigned to them. In the third paragraph of the same article the Commission is assigned with the power to invigilate the accordance with the provisions under the mentioned paragraphs: «[u]ndertakings entrusted with the operation of services of general economic interest or having the character of a revenue-producing monopoly shall be subject to the rules contained in the Treaties, in particular to the rules on competition, in so far as the application of such rules does not obstruct the performance, in law or in fact, of the particular tasks assigned to them. The development of trade must not be affected to such an extent as would be contrary to the interests of the Union.». Hence it can be deduced that the derogations to the ordinary regulation of economic activities first of all find general limits which can be summarised in the necessary respect of the principle of proportionality, in the sense that they must consist in necessary and apt measures to the above mentioned primary goal. Sometimes the Union has required that the exception to the ordinary regime presume the non-existence of alternative measures, less limiting to competition, but the European Court excluded that it should fall on the Member State to prove that no other measure could enable those tasks to be performed under the same conditions $^{22}$.

The second point to reflect upon to generally set the matter at hand in context is represented by the «social» profile, or, according to the expression used in the European discipline, by compliance with the principle of subsidiarity in the provision of services; this is an aspect that has always been typical of the Italian system, but it however finds precise collocation within EU principles: suffice it to reference the

22 See Judgment of the Court of 23 October 1997. Commission of the European Communities v Italian Republic. Failure of a Member State to fulfil its obligations - Exclusive rights to import and export electricity. Case C-158/94.
Treaty on the Functioning of the European Union, under Article 14 (ex Article 16 TEC) where, stressing the relevance of services of general economic interest, the specific role played by such services in promoting the social and territorial cohesion of the Union and in Member States is recognised, as well as in the application of the Treaties, which must take care that such services operate on the basis of particular economic and financial conditions. Even if according to the social relevance of the services a less liberal approach is preferred, their traceability to the discipline of EU principles on competition and internal market remains firm, since such principles are connected to the economic freedoms granted within the Common Market ${ }^{23}$.

It is worth mentioning that on this matter the European Commission again highlighted the social dimension of the services, both in the "Single Market Act: The Next Steps to Growth" of April 2011, and in the subsequent Communication of October 2012, the «Single Market Act II Together for new growth» where the necessity of also reinforcing social cohesion via the service sector is forcefully restated.

Indeed, in Italy, after the rejection of the outdated distinction between public service in the objective sense and public service in the subjective sense, the choice was made to use a point of view dictated by «functional» rules, having the objective of identifying a criterion that was more dynamic and consistent with the needs of the community; evidently under the influence of the Union, which had already laid down regulations differing from those usually received by the Italian system.

On the other hand, it is from this presumption that the relevance taken on by the matter nowadays emerges, bearing great significance on account of the financial burden that the SGEIs ${ }^{24}$ have acquired from a macroeconomic point of view, as may be deduced by the hearing at the Italian Camera Affari costituzionali (House of Deputies, 25 January 2012) where it was noted that in Italy local public services involve more than 137,000 workers and produce a turnover amounting to around 35 billion Euros; consequently the proposed changes imply intervening what amounts to $3 \%$ of the GNP.

The economic significance of the services has acquired a specific role also in the agenda of EU institutions, thus making the necessity of a rethinking on the part of all Member States, Italy included, of the logical and legal prerequisites of the sector, especially for the consequences that the activities they operate have on the market, on competition, and eventually on the economies of single states.

${ }^{23}$ R. Ferrara, Profili della disciplina dei servizi di interesse economico generale: aiuti di Stato e principi dell'Unione europea in materia di concorrenza, in Il diritto dell'economia, vol. 26, n. 81 (2-2013) pp. 324 and following.

${ }^{24}$ G. F. Cartei, I servizi di interesse economico generale tra riflusso dogmatico e regole di mercato, in Riv. It. Dir. Pubb. Com., 2005, pp. 1221 and following. 


\section{SGEI the Principle of Competition for Services of General Economic Interest: The Criteria of Proportionality and Balance in the European Community}

The process of European integration has given urgency to the construction of a single European market through the elimination of the obstacles to the free movement of goods, capitals and persons, ratifying the freedom of establishment and freedom to provide services. In this framework, then, we must examine the implementation of the principle of competition in economic public services, where the sector, thanks to the provisions in the Treaties, although acknowledging the freedom of Member States in the organisation of services, expects that an open market amongst the economic operators be the hub around which all public or private subjects offering goods or services in a given market turn.

However, we must take note that in the matter of public services even today a great number of administrative regulation are to be found, often ancient, and frequently having a corporative inspiration, introducing rather detailed limitations, such as to successfully preclude effective competition, and by this we are not exclusively referring to the Italian model.

In any case, as previously discussed, European regulations on public services find their foundation in Article 106, paragraph 2, TFUE, which states «Undertakings entrusted with the operation of services of general economic interest [...] shall be subject to the rules contained in the Treaties, in particular to the rules on competition, in so far as the application of such rules does not obstruct the performance, in law or in fact, of the particular tasks assigned to them》.

However, in EU law, the expression «rules of competition» takes on a specific legal meaning, because as stated under Article 119 TFUE, the Union follows «an economic policy [...]conducted in accordance with the principle of an open market economy with free competition.».

It is thus necessary to endorse the interpretation identifying the fulcrum of Article 106 TFUE specifically in the relationship arising between the States and the undertakings managing the services, and also the position of the latter on the relationship with the Treaty; one instance for all are the references made by European case-law where it is often remarked that Article 106 of the Treaty useeks to reconcile the Member States' interest in using certain undertakings, in particular in the public sector, as an instrument of economic or fiscal policy with the Community's interest in ensuring compliance with the rules on competition and the preservation of the unity of the Common Market ${ }^{25}$.

25 Judgment of the Court of 19 March 1991. French Republic v Commission of the European Communities. Competition in the markets in telecommunications terminals equipment. Case C-202/88. 21.09.1999, case 202/88 French Republic v. Commission; see also Judgment of the Court (Grand Chamber) of 20 April 2010. Federutility and Others v Autorità per
This also entails that when the local authority chooses a regimen of monopoly, the choice of the contractor must be made via open (public) tender in compliance with the principle of a competition. The Italian Constitutional Court itself has recognised that "a national rule allowing the assigning of public services without a competitive procedure» would be against European law, pointing out that «such an assignment is against Articles 43 and 49 of the TEC or, even, the principles of equal treatment, non discrimination transparency»

The concept of «competition» or, to be more precise, «rules of competition» has thus come to assume, pursuant to the Court of Justice case-law, a so to speak «container» function, inasmuch as it may have as object the most diverse interventions, albeit all in essence aiming at ensuring the effectiveness of said principle from the point of view of the EU.

It is thus obvious that the expression «rule of competition» under Article 106, paragraph 2 TFUE, has recently assumed the outline of a solid discipline, both from the point of view of the interests involved, and the management dynamics within the field of competition. So that the provision for the tender procedures for the assigning of the managing of a public service of economic interest must be ascribed to the so-called «competition for the market» thus becoming the premise before the so-called «competition within the market». It is in this landscape that it is necessary to underline that «competition for the market» may be considered as adequate, but not exclusive, tool to reduce the instances of a monopolistic management of services ${ }^{26}$.

So the economic relevance of a service is the sine qua non for it to be the origin of the applicability of EU law within the national law system, the enforcement of the principle of competition and the prohibition for States to help the undertakings charged with managing and choosing the model for the management of the service itself.

It is obvious that entrusting the qualification of economic action in a differential key from social activities or public functions in the strict sense to national systems or public administrations $^{27}$ would lead to jeopardizing the aims of the

l'energia elettrica e il gas. Reference for a preliminary ruling: Tribunale amministrativo regionale per la Lombardia - Italy.

${ }_{26}$ See Judgement of the Court of Justice of 22 May 2003, case C- 18/2011. Also of interest the reference to Judgement of the Council of State, Section V, of 23.10 .2012$, n. 5409 .

${ }^{27}$ The following have been considered typical prerogatives of public powers, not possessing economic character: control an policing of air space (Judgment of the Court of 19 January 1994. SAT Fluggesellschaft mbH v Eurocontrol. Case C-364/92. In Reports of Cases 1994 I-00043); pollution prevention in harbours (Judgment of the Court of 18 March 1997. Diego Calì \& Figli Srl v Servizi ecologici porto di Genova SpA (SEPG). Reference for a preliminary ruling: Tribunale di Genova - Italy. Harbour company Prevention of pollution - Legal monopoly - Abuse of a dominant position. Case C-343/95. In Reports of Cases 1997 I-01547); National education (Judgment of the Court of 27 September 1988. Belgian State v René Humbel and Marie-Thérèse Edel. Reference for a preliminary ruling: Justice de paix de Neufchâteau - Belgium. Non-discrimination - Access to education Enrolment fees. Case 263/86. In Reports of Cases 1988 05365, c. 263/86, points 17-19). On the other hand, the public employment agency was considered an undertaking for the purposes of the application of EU competition rules, (Judgment of the Court (Sixth Chamber) of 11 December 1997. Job Centre coop. arl. Reference for a preliminary ruling: Corte d'appello di Milano - Italy. Freedom to provide services - Placement of 
Treaty, narrowing the field of application of the rules of competition to the detriment of users within the notion of universality of service and its accessibility, not to mention the fallout in terms of fees and tariffs ${ }^{28}$.

If SGEIs perform an economic activity subject to service obligations - since in the absence of such an obligation the activity would not be guaranteed to the community - it derives that the absence of economic expediency would compromise the supply and consequently the performance of the service itself; it is only in his case that the offer of the service implies the intervention of public powers in terms of help, i.e.: compensations ${ }^{29}$. The fact is that in this hypothesis, only the subrogating intervention of public powers is capable of guaranteeing performance.

So, the search for a balance between the values of economic and social cohesion (that is the assurance of the realisation of forms of public intervention aiming at safeguarding the general interest in the satisfaction of needs considered essential for citizens/users) and the observance of the principle of competition (which concerns all economic operators interacting in various capacities within the European Union) represents the real focus of the matter.

With this there is the wish to take on the principle of the balance between the opening of the market in the field of public services, especially those having economic relevance, and the rights of solidarity and non-discrimination amongst users: these principles must find a correct combination in each Member State, in conformity with the prohibition of state aid provided for under the Treaties.

This is the result of a desire to react to the many nuanced factual situations the matter produces, having to acknowledge the existence, sometimes, of situations of substantial and formal inequality, which public authorities have to respond to by strategic options; for instance compensating those undertakings that accept operating, with lower profits, in favour of those classes and categories of users that would be disadvantaged if suitable interventions of

employees - Exclusion of private undertakings - Exercise of official authority. Case C-55/96. In Reports of Cases 1997 I-07119 points 21 e 22, Judgment of the Court (Sixth Chamber) of 23 April 1991. Case C-41/90.), while for the activities of social security and assistance have no economic characters, when the latter are based on the principle of solidarity, that is on a compulsory subscription system that ensures the managing entity's financial balance and the services provided are independent from the contributed sums (Judgment of the Court of 17 February 1993. Christian Poucet v Assurances Générales de France and Caisse Mutuelle Régionale du Languedoc-Roussillon. References for a preliminary ruling: Tribunal des affaires de sécurité sociale de l'Hérault - France. Interpretation of Articles 85 and 86 of the EEC Treaty - Concept of undertaking - Organization charged with the management of a special social security scheme - National legislation attributing a dominant position to such an organization. Joined cases C-159/91 and C-160/91. In Reports of Cases 1993 I-00637).

$28 \quad$ Confirmation comes pursuant to Article 1, paragraph. 3, of Directive 2006/123/EC of the European Parliament and of the Council of 12 December 2006, on services in the internal market, which states «This Directive does not affect the freedom of Member States to define, in conformity with Community law, what they consider to be services of general economic interest, how those services should be organised and financed, in compliance with the State aid rules, and what specific obligations they should be subject to».

29 The identification of public services as an economic activity is not new to the Italian system, suffice it to recall two judgements of the Constitutional Court, no. 203, of 17.3.1988, and no. 104, 20.12.1988, where the Court already noted the essential relation between the concept of public service and the notion of undertaking. social and economic equalisations were not implemented. On other occasions, what must be considered is the fact that the providers do not have competing undertakings due to the objective lack of an actual market in the sector of providing public services, sector which has suffered for years from political influence and choices aimed at monopolistic systems closed to an effective plurality of operators. To this end, an ad hoc procedure has been defined, as natural setting for their synthesis: the Commission, after having assessed the indispensability and the proportionality of the amount of help, is bound to verify its incentivising nature, that is, it is obliged to assess if the financial support is commensurate to the added costs the undertaking is available to commit to; thus it is the benefit from the point of view of the overall social and economic aspect that makes the aid compatible with the EU system.

The Court of Justice, indeed, has, for years, confirmed its interventions on the principles in its judgement in the Altmark $^{30}$ case, which has represented the reference point for the whole matter, especially under the profile of compensation, as factual paradigm of the principle of proportionality that was referred to previously. In this judgement, the EU Court, after having referred to the necessary premises for qualifying State intervention measures as «State aids», highlighted the adequacy of State aid measures by recognising «an advantage» to the undertaking benefiting from them; «public subsidies granted to undertakings expressly required to discharge public service obligations in order to compensate for the costs incurred in discharging those obligations [...] do not fall within Article 92(1) of the Treaty» ${ }^{31}$. To the original framework represented by the Altmark judgement, the four documents composing the so called Almunia Package have been grafted, three of which - the Communication, the Decision and the Framework - were adopted by the Commission on 20.12.2011, while the de minimis Regulation was published on 26.4.2012 ${ }^{32}$. In the Communication from the Commission, an initial part reconstructs the notion of State aid, as outlined by the Court of Justice's case-law, while the second part restates the Altmark conditions, which lead to the exclusion the of compensations of public services from the notion of State aid. The package adopted by the European Commission on 20.12.2011 (which has replaced

${ }^{30}$ Judgment of the Court of 24 July 2003. Altmark Trans GmbH and Regierungspräsidium Magdeburg v Nahverkehrsgesellschaft Altmark $\mathrm{GmbH}$, and Oberbundesanwalt beim Bundesverwaltungsgericht. Case C-280/00, in Reports of Cases 2003 I-07747, on the latter's concession, on the part of the Magdeburg regional Government, of the operation of urban, suburban and regional scheduled transport services

31 Point 94. Article 92 Paragraph 1 of the Treaty later became article 87, Paragraph 1 TFEC. In the meanwhile said article of the TEC has become the current Article 107 del TFUE which lays down that the State Aid to an undertaking managing an SGEI shall be compatible with EU rules on competition in the presence of the four conditions in the Altmark Court of Justice.

32 It must be recalled that Regulation No 360/2012 of 25 April 2012, on the application of Articles 107 and 108 of the Treaty on the Functioning of the European Union to de minimis aid granted to undertakings providing services of general economic interest, that is those aids of modest amount, identifies the interventions for which there is an exception to the mandatory notification to the commission in order for it to exercise suitable control. 
the 2005 Monti-Kroes package) ${ }^{33}$, introduced more detailed provisions compared to the previous regulation. More in detail, the Almunia Package introduced a new perspective in the evaluation of compensations in the matter of SGEIs, giving a prediction of the compensation ex se also for the purpose of achieving a possible reduction of the public expenditure including tariff costs.

At a closer look the Almunia Package marked a significant step forwards to frame the nature of compensations, as highlighted by the first Commission Decision relative to the case for the compensation for a network of undertakings operating in the English postal sector, to which the discipline on SGEIs for the years 2012/2015 was extended. In the abovementioned case the Commission not only examined the compatibility of the adopted measures with the regulation on public contracting, it also elaborated precise calculations to determine compensation. Undoubtedly there emerges from this decision that the Almunia package constitutes a reference point in the Commission's future decisional praxis, contributing to the generation of a higher legal certainty in evaluating compensations for the provision of public services. It may be observed that these new measures provide Member States with precious details on the qualification of compensations, especially in the moment when the latter directly or indirectly influence internal markets, financial aspect, tariffs or, more in general, the status of competition.

\section{National Regulations on Local Public Services of Economic Interest: The Difficult Implementation of EU Principles in Italy}

If from the EU level the focus shifts to the Italian system, the first remark emerging from Italian national regulations is that it was only from the entry into force of Law 142/1990 that the idea of offering public services via management modules that were different from the actual public, political bodies, emerged, in order to characterise the provision of the latter according to criteria of efficiency and economicity; this entailed (or should have) the creation of not just new models of supply (characterised by patrimonial autonomy, detachment from local entities, and the aim of balancing the budget) but also a rethinking the latter's relationship with the local authorities, and towards the users themselves.

Fundamentally, from then on, and with greater clarity in

33 Said package consists of three operative instruments: Commission Decision 2005/842/EC: of 28 November 2005 on the application of Article $86(2)$ of the EC Treaty to State aid in the form of public service compensation granted to certain undertakings entrusted with the operation of services of general economic interest (notified under document number C(2005) 2673, in OJEU L 312, 29.11.2005, p. 67-73; Commission Directive 2006/111/EC of 16 November 2006 on the transparency of financial relations between Member States and public undertakings as well as on financial transparency within certain undertakings (in OJEU L 318/17 of 17.11.2006); Commission Community framework for State aid in the form of public service compensation in Official Journal C 297, 29/11/2005 P. $0004-0007$. the subsequent period, it became reasonable to think, in order to qualify a public service as having economic relevance, that it was not the typology of service per se that had to be considered, but rather the significance the supply of the given service would have on a given market; significance that, moreover, should condition the organising solution that the local authorities considered the most appropriate to fulfil citizens' expectations.

Culturally, a dynamic and evolutionary concept of the distinction between public economic service and non-economic public service was asserted, moreover admitting the option, for public powers, of being able to modify the use of one management model rather than another, where such changes were capable of guaranteeing a better efficiency in the supply of services, taking into account the interests of users, which should guide choices in policy, to consequently achieve the aim of leaving to the free market the management of certain economic activities, even in the case of the latter being previously managed under monopoly.

The notion of economic relevance has imposed an assessment on the same activity, not simply in relation to the structural features of the production of goods and services, but also to its profiles relative to the specific activities the operator carries out for the service required, that is the (economic) relevance that may exist also for subjects that must (or aspire to) interact with the authority entrusted with the public service.

After Law no. 142/1990, the management of local public services of economic relevance has more and more received the principles of the EU system; the outcome of this evolution is represented by Article 23 (a) of Law decree no. 112 of 25 June 2008 , n. 112, which, providing a specific legal regimen for the so called «economic public services», opened the doors to a pro-competition legislation on the matter, inspired by the European model.

Despite the legislative structure favouring a regimen opened to the market, at least from the point of view of the adoption of «private law» models, the idea was that, in the hypothesis of operating within a monopoly, the local authority could resort to keeping the three typical management models, all characterised by a common feature: they all entailed the attribution of exclusive rights to one economic operator, either private or public, chosen by open tender.

Article 23 (a), paragraph 2, as amended by Conversion Law no. 113, of 6 August 2008, confirmed with renewed vigour the distinction between services within the market and services removed from the market; for the latter the traditional types of service management remained based on the attribution of exclusive rights since the public entity's intervention presumed a lack of market and competition in the economic activity that was supposed to be "elevated" to the rank of public service, satisfying the public law regulation of the sector. It is in this perspective that Article $23(10)(\mathrm{g})$ declared itself to be the outcome of a Regulation 
with the purpose of limiting «according to criteria of proportionality, horizontal subsidiarity, and economic rationality, the cases of exclusive management of local public services, by liberalising other economic activities providing general interest services locally, compatible with the guarantees of universality and accessibility of public services».

From the very first reading of the Regulation issued to apply the above mentioned rules ${ }^{34}$, there emerges the introduction of a regulation with the tendency to dissuade from recourse to a monopoly system: local bodies, in particular for economic services, in full compliance with the principles of competition, of liberty of establishment, and free supply of services, should have first of all verified the feasibility of a competitive management even in the sector examined, limiting the attribution of exclusive rights only when free private initiative did not result capable of reaching the target of guaranteeing universal supply to users. It must be kept in mind that Article 2 of Presidential Decree $168 / 2010$ set down that local bodies shall, first of all, verify the feasibility of a competitive management of local public services, limiting the granting of exclusive rights «where the law does not provide otherwise». It was the duty of local authorities to verify whether certain public services could be performed by the market, with the consequence that the recourse to exclusive rights was pursuable only in the case of those activities for which free economic initiative did not answer the needs of the community.

Thus, if in the 1990 regulation the objective was that of realising so called formal privatisations, since 2010 a real privatisation has been attempted, in the wake of $\mathrm{EU}$ principles this is confirmed by certain passages referred to in the provisional framework introduced under Article 23 (a):

- firstly, the object of the regulation was focussed on the choice between the liberalisation of the activities of local public services and bestowing their management by exclusive rights;

- secondly, the prerequisites for liberalisation were to be found in the services' compatibility with the features of universality and accessibility, so that the prerequisites for bestowing exclusive rights were identifiable with the absence of private economic enterprises capable of ensuring their provisions;

- thirdly, in order to make a choice, a verification procedure had to be put in force, in which determining relevance was entrusted to market analysis, which then became the paradigm for administrative action.

It is however necessary to observe that this has not occurred via a general regulation - whose proposals for revision have always remained on paper because of the resistance of public administrations, in order to keep the

${ }^{34}$ Presidential Decree no. 168, of 7 September 2010, regulation on local public services of general relevance, pursuant to article 23(a), Paragraph 10, of Law Decree no. 112 of 25 June 2008, passed, with amendments, into law no. 133 of 6 August 2008 . supply of services under their control - but by modifying, in turn, the jurisdiction of local bodies, and specific types of service. This seems to be the «original sin» that the subject suffers from, this type of sectorial legislative intervention having rendered the general picture extremely uncertain, and imposed that, in order to operate according to the EU model lip service is paid to, and whose declarations of principle are proposed time and time again in all relevant legislation, only specific interventions were carried out and there was no overall framework.

The referendum which took place in Italy on 12 and 13 June 2011, had as object the repeal of article 23 (a); the outcome of the latter also determined the implicit repeal of all provisions under Presidential Decree no. 168 of 7 September 2010, raising numerous interpretative questions on what was the regulation to be enforced given the legislative vacuum thus created. As mentioned in our introduction, the Supreme Court, however, in its Judgement no. 199/2012, referred to EU laws and not to the national laws preceding the law subject to referendum, despite the fact that the previous national laws were inspired by EU regulations.

The matter of SGEIs in the Italian system was further "enriched" by the introduction of Law no. 183 of 12 November 2011, (2012 "Stability Law"; but the national legislature had already intervened with Law Decree no. 138 of 13 August 2011, amended and converted in law no. 148 of 14 September 2011, named «Ulterior urgent measures for financial stabilisation and development».

There results a national regulation that actually - although with different declarations - simply echoes the provisions under Article 23 (a) of Law no. 113 of 6 August 2008, n. 133 on competition, although the latter claims to clarify certain essential aspects for the correct enforcement of the principle at stake, with particular reference to the pragmatic assessment of indications from the market to determine models for the management of services. This observation is supported by the provisions under Article 4 of the Law Decree no. 138/2011, as emended by Law no. 148/2011, which provides that [ [...] local authorities, pursuant to the principles of competition, of freedom of movement, and free provision of services, after having identified the specific contents of universal public service obligations, verify the feasibility of a competitive management of local public services of economic interest, hereby local public services, liberalising all economic activities, compatibly with the characteristics of accessibility and universality of the services, and limiting, in other cases, the bestowing of exclusive rights in the hypothesis that, on the basis of market analysis, free economic enterprise should not appear capable of ensuring a service fulfilling the needs of the community.»

It is then laid down that the administration is supposed to carry out an assessment and following the latter it should adopt a framework resolution outlining the investigation carried out and justifying the reasons leading to the removal 
of certain services from the free market ${ }^{35}$.

The ratio of the regulation indicates the way in which the local authorities may also manage an economic public service under monopoly, or decide to privatise a certain economic activity, even if falling under the definition of public service tout court. The mind frame inferable from the legislative data is expressed by the necessary procedure aiming at progressively rendering as objective as possible the parameters which should justify the choice between public services and liberalised sectors. It can only partially be said that the legislators have taken the Constitutional Court's «hint» prospected in Judgement 199/2012, where the touchstone was set in the distinction between economic public service and non-economic public service, leaving such a distinction not to an apodeictic identification, but to the relationship between the organisation of the service and the market.

Local authorities, to guarantee citizens/users the provision of public services whose object is the production of goods and services with the aim of achieving social goals and promoting the civil and economic development of a given community, are bound, under the provisions of Paragraph 5 of Article 4 of Law 148/2011, to preliminarily define any possible economic compensations to the undertaking supplying said services, within the limits of the budget resources allotted to the purpose, moreover taking into account the proceeds deriving from the tariffs ${ }^{36}$.

The provisions declared unconstitutional by the Court in its Judgement no. 199/2012 are set out yet again in the subsequent provisions laid down under Article 34, Law Decree no. 179 of 18 October 2012, included in Law No $221 / 2012$, where the necessity of guaranteeing free competition «under conditions of equal opportunity and a correct and uniform operating market» is declared, in order to guarantee consumers conditions of accessibility to goods and services on all of the [national] territory. It must be observed that Article 34(20) of legislative Decree no. $179 / 2012$, passed into Law n. 221/2012, provides that «in the case of local public services having economic relevance, in order to ensure compliance to EU regulation, equality between operators, cost effectiveness of management and guaranteeing adequate information to the reference community, the service is bestowed on the basis of an ad hoc report, published on the website of the contracting authority, which accounts for the reasons and the existence of the prerequisites required by the EU regulations for the type of contract chosen and defines the specific public and universal

\footnotetext{
35 Consistently, Paragraph (2) of Article 4, Law no. 148/2011, provides that «at the end of the analysis under Paragraph 1 the body issues a framework resolution describing the investigation carried our and highlights the reasons of the decision regarding the sectors removed from liberalisation, and illustrates the benefits deriving from the maintaining of an monopoly system for the». Under Paragraph 3 of the same article, «such a resolution must be adequately advertised, it is sent to the Italian Competition Authority, also for the purpose of the report to Parliament provided for under Law no. 28 of 10 October 1990 .

${ }^{36}$ In this sense there is a restatement of what had already been established in the famous Altmark judgement of 24.07.2003, case C-280/00.
}

service contents, indicating economic compensations if provided for».

This provision moreover inserts itself in the provisions under Article 34 of Law Decree no. 201 of 6 December 2011 which had already stated - and could do no differently - that the performance of an economic activity is marked by the principle of freedom of access «excepting the imperative needs, relevant to and compatible with the EU legal system, that may justify the introduction of previous administrative acts of approval or authorisation or control, in compliance to the principle of proportionality». Even more relevant, for the aspect here examined, are the provisions under Article 1 of Law Decree $1 / 2012^{37}$, which, referencing the liberalisation of economic activities and the reduction of the financial onuses of the undertakings, in virtue of the provisions of Articles 41 and 117 of the Italian Constitution, set out the repeal of rules laying down prohibitions and restrictions to economic activities when the former are not adequate and proportional to the public purposes pursued, thus again ratifying the privatisation of these, including SGEIs.

On the other hand, it is impossible to underestimate the fact that in judgement No. 199/2012, the Court of Cassation, referring to EU law as parameter, lays down that the former « [...] allows, even though it does not impose, the direct management of the public service on the part of the local authority, when enforcing the rules of competition prevents, de iure or de facto, the public authority's special mission». In conclusion, the Court's intervention actually causes a return to the previous regulation framework: the Administration may also directly manage public services having economic relevance, according to traditional models, but this does not entail that, pursuant the judgement, services once externally provided are made to be internally provided By way of demonstration that the set up on the matter remains the one outlined by the repealed regulation, there is the important fact that Article 4, although declared unconstitutional, performs its effects though other provisions present in the field: this is inferred by the provisions under Article 3 of law Decree 138, combined with the provisions under Article 34, Law Decree 201/2011, as well as those under Article 1 of Law Decree no. 1/2012. The keystone of the system is represented by the fact that, according to the provisions of Law Decree 201/2011, the introduction of an administrative rule aiming at making the performance of an economic activity subject to previous authorisation must be justified on the basis of the existence of a general interest in compliance to the principle of proportionality. The Italian Competition Authority shall issue an opinion on the matter of the motivation of the choices made by the Administration, thus leaving the market's economic activities to the market,

\footnotetext{
37 Disposizioni urgenti per la concorrenza e lo sviluppo delle infrastrutture e la competitività, (Urgent provisions on competition and the development of infrastructure and competitiveness) in the Official Journal of the Italian Republic, no. 71, of 24 March 2012, n. 71.
} 
and intervening only in the case of the market not being capable of ensuring a given service.

Finally, mention should be made of Article 34 of Law Decree no. 179/2012, converted in Law no. 221/2012, by means of which the Italian legislators set down a de minimis regulation on the entrustment of public services. From a first perusal of Law Decree 179/2012 there emerges that an attempt was made to intervene on the matter, and while this does respond to the necessary specificities of the single services, it makes the implementation of the provisions themselves much more difficult. But the crux the present work focuses on is the fact that even in this new discipline a procedure is introduced as a «balancing space» between the political and the economic assessment of choices made regarding the organisational model, also on the basis of the social cost produced by such choices. It is the political body who remains responsible for meeting the fundamental needs, as expressed by the current system, or rather the single requirements of the local areas, in order to assess the fulfilment of the needs of the whole community such as accessibility, continuity and safety, besides the social costs of the services themselves. The premises which should guide the entity's choices on the matter, under Law Decree 179/2012, subsequently converted in Law no. 121/2012, are to be declared in an ad hoc report published on the local authority's website, explaining the reasons and the existence of the prerequisites provided for under the EU system for the type of assignment chosen and also defining the specific contents of the public service and universal service obligations, identifying, if provided for, any economic compensation (Article 34 Paragraph 20). It appears obvious that the Law Decree was meant to provide a nucleus of obligations for mayoralties, in the repeated attempt of imposing the respect of EU principles to local authorities, principles conditioning the choice of managerial models to ensure the compliance of the models used to EU regulations.

However, if the procedure under the repealed discipline is compared to the following regulation, i.e. Article 4 of Law 148/2011 and Article 34 of Law Decree 179/2012, it appears that, even considering the diversity of certain, specific aspects, both tend to instruct local bodies to objectively demonstrate the possible non-existence of conditions justifying the liberalisation and competitiveness in «the market», thus avoiding any elusion supporting the preference for the attribution of exclusive rights for the purpose of prospecting a distorted identification of the needs of the community. Indeed, the previous regulation set out that the Italian Competition Authority had to intervene by issuing a compulsory opinion on the proceedings, (and this solution appears to be more consistent with the aims pursued) while from the literal contents of the rather muddled provisions under Article 34 of Law Decree no. 179 of 18 October 2012, n. 179 , it appears that the assessment by the entity is only subject to an obligation of accessibility, falling under the provisions relative to the administration's discretionary choices. However, this choice, to be seriously worthwhile, should fall under the concept of discretion in the meaning deriving from studies in administrative law, that is not arbitrariness, but consideration of the interests at stake.

The adoption of a procedure objectifying the parameters of the Administration's action, moreover, adheres better to what has constantly been established by EU case-law ${ }^{38}$, which has, time again, stressed that evaluating the circumstances and conditions of services provided appertains to the national legislature. Actually, the EU imposes an assessment of services of economic importance that takes into account, besides the teleological profile of the services, - that is the nature of the collective interests and needs to be fulfilled - the organisational aspect, that is the way said services will be provided - as well as the strictly economic profile and the impact the activities may have on the market and in particular on the tariffs borne by private subjects.

However, one objection to the most recent Italian legislation is the way the latter is expressed: it appears that the motivations of the solutions adopted by the authorities on services are bound to the initial moment of choice, while nothing is said about possible later confirmations. This because only the reiteration of market analyses at regular, non-excessively spaced intervals, and not just in the initial phase, as on the contrary the Italian legislators seem to provide for, seems suitable to test the continuing existence of the prerequisite universality in relation to different socioeconomic moments.

It must be observed that, even in the case of services managed under monopoly, the principle of competition is not extraneous to the latter, if competition means the verifying of a given organisation's capacity to achieve the aims of economic and social satisfaction in providing services.

The fact is that public services, even when they are of economic relevance, cannot see their social nature diminished on the basis of the erroneous premise that the undertaking entrusted with their provision may ensure its operations only provided that there is an equalising public intervention; on the matter of the production of services it is the factual datum that conditions the type of organizational model suitable for its management, as parameter for the optimisation of the fulfilling of the requests of users and of the market. Consequently, it must be considered that the production of services is in itself strongly dependent on the interactions between solicitations issuing first of all from the market and more in general from the "external environment", including the so to speak geographical data of the optimisation context of the service and the «role» of the citizens/users. It has been observed that $«[\ldots]$ what level of distributive equity, and in general, what level of equality and social justice must be achieved is a matter of political choices; what standard of efficiency in allotting to achieve is,

38 See Judgement of the European Court Of Justice of 22 May 2003, case $18 / 2001$ and the Judgement of the Italian Constitutional Court no. $272 / 2004$ 
instead, matter of economic choices, directly pertaining to market forces». 39

However, even if one believes that such premises are by now acquired knowledge on the part of the legislators, it is impossible to comply with this mind set by persisting in thinking that the administration should make an operational choice whence it becomes difficult to deviate; in this way one takes one of the typical connotations of the «bureaucratic organisational model» contrasting with the capacity administrative action to adjust to external changes, as confirmed in services of economic relevance.

Nor can it be objected that by acting this way there would be an increase in the number of «structures» or, more in general, providers, since when varying the management model there should also be the courage of varying the providing structure, thus, by the way, achieving the aim of slimming down the «administrative providing system» by not keeping the various municipal, public, public-private, and house providing undertakings immovable and unchangeable.

Such a situation cannot exclude alternative modalities of satisfying the needs of the community, by recourse to new and different ways to provide services; thinking in a different way would entail that current service providing structures would assume the role of "obstacles to the integration between the different levels of public action, undermining at their foundation the hypotheses of revision at an institutional level» ${ }^{40}$.

If there is no compliance to these principles, there incurs what has been called «the arrogance of optimism», defined by the unwavering endorsement of the illusion of the efficiency of public administration, not taking into account a no less relevant element which should guide the action of public powers, that is the necessity that the public apparatus providing services adapt to external factors, such as the market, which should be a fact conditioning the managing of the service itself.
As Crozier highlighted, it is not a coincidence that one of the bureaucratic model's own connotations is identifiable in the incapacity of said model to adapt to changes, and it is the adherence to the bureaucratic model that ill matches the field of services. Indeed, the bureaucratic organisational model «surrenders to change only when such serious malfunctions have occurred that it has become impossible to deal with the latter, thus originating an evolutionary mechanism to face the crisis» ${ }^{41}$. On the contrary, it is the testing of the achievement of the objective connected to the adoption of a management model that legitimises a monopoly, compared to a competitive system.

Besides, if the starting point is that the principle of competition represents the inspiring principle in the matter, it has to be admitted that even in the case of a service managed under a monopoly, the competition of a plurality of managers may and must always be provided for, so that the final user may not only evaluate the equality of service but also the price charged.

Thus the principle of competition must be implemented not just in the case in the case of competition «for the market», but even in the case of competition «within the market», by the provision of the same services by more than one contractor; it appears fitting to implement, even in the case of local public services, this criterion, by now fully acquired for the so called network services - assuming the concept of network not as a concrete, but as an abstract one as moreover seems to have been timidly hinted by the Italian legislature in Law no. 221/2012.

The actual fact is that the reiterated verification of adherence of the choices made by the public entity to the needs of the community and of the market, both in the hypothesis of outsourced services as well as in the choices the users may make between different contractors in the case of monopoly, places the citizens and users at the centre of the system.

It is necessary to recognise the citizens/users' capacity to make an impression by their behaviour, both as single individuals and as a community, on the execution of and on the models for the provision of services.
39 P. Bianchi e G. Gualtieri, in Introduzione al volume concorrenza e controllo delle concentrazioni in Europa, eds. G. Bianchi and G. Gualtieri, Il Mulino, Bologna, 1993, p. 10.

${ }_{40}$ G. Della Cananea, Stato e mercato: le infrastrutture per i servizi pubblici, in Riv. Munus, no. 1/2013, p. 2 and following.
${ }^{41}$ M. Crozier, Il fenomeno burocratico, Etas Kompass, Milan, 2000, p. 130 and following. 